\title{
EFFECTS OF LIGHT REGIMENS AND VITAMIN D3 LEVELS AND THEIR INTERACTIONS ON BROILERS GROWTH PERFORMANCE AND CARCASS TRAITS.
}

\author{
M. A. Metwally, M.F.A. Farghly and T.M. Sharaqa \\ Department of Poultry Production, Faculty of Agriculture, University of Assiut, Assiut, Egypt, 71526
}

(Received 19/1/2021, accepted 23/3/2021)

\section{SUMMARY}

\begin{abstract}
he present study was designed to investigate the effect of light regimens and vitamin D3 levels on
$\mathrm{T}$ growth performance and some carcass traits of broiler chickens. Two hundred and seventy birds were randomly assigned in factorial design (3x3). Three light regimens ( $24 \mathrm{hrs}$ continues light, $12 \mathrm{hrs}$ continues with $12 \mathrm{hrs}$ flashlight and 24 hrs flashlight) and three vitamin D3 levels (0, 200 and 400 IU). Nine treatments of 30 birds each (three replicates of 10 birds each). The birds were housed in floor pens from day one till six weeks of age. Feed and water were available ad lib. and all conditions were the same during the experimental period. The results showed that significantly affected body weight, daily weight gain and feed conversion ratio. In addition, birds reared under continuous with flashlight and feed with 200 IU Vit. D3 had significantly $(\mathrm{P} \leq 0.05)$ better body weight, daily weight gain , feed conversion and some carcass traits compared to the other groups. Finally, birds reared under continuous with flashlight and feed with $200 \mathrm{IU}$ Vit. D3 was better than the other groups and was recommended to the poultry producer.
\end{abstract}

Keywords: Broilers, light regimens, Vitamin D3 levels, Performance

\section{INTRODUCTION}

Nelson et al., (2020) observed that birds in the intermittent, short-dawn/dusk photoperiod (ISD) treatment were heavier on day 45 of age. Olanrewaju et al., (2019) showed that broilers subjected to regular/intermittent photoperiod increased body weight on day 14, day 28, day 42, and day 56 of age. Farghly et al., (2019a) reported that the interaction between feeding regime and lighting program affected the growth performance. however, broilers exposed to flashing light and an intermittent feeding regime had the highest body weight (BW) values of all the groups. Olanrewaju et al., (2018) showed that broilers subjected to the short/non intermittent (8L:16D) photoperiod had the lowest body weight compared to other two photoperiods. Metwally et al., (2015) reported that light type significantly affected body weight.

Olanrewaju et al., (2019) showed that regular/intermittent photoperiod increased BWG on day 14, day 28, day 42, and day 56 of age in comparison with short/non-intermittent photoperiod. Arowolo et al., (2019) reported that various degrees of intermittent photo-period rather than one continuous photoperiod have been proven to significantly improve broilers' weight gain by 3.4-5.8\%. Fidan et al., (2017) observed improvements in weight gain in a group of broilers subjected to increasing duration of photoperiod at $42 \mathrm{~d}$ compared to the birds on 23L: 1D treatment (2947.36 g vs. $2916.72 \mathrm{~g}$ ) even though there was no significant difference in the feed consumed by the two groups. Subsequently, the distribution of photoperiod (light hours) and scot period (dark hours), which is one of the components of lighting program for broilers, has been reported to influence growth performance .

Olanrewaju et al., (2018) showed that broilers subjected to the short/non intermittent (8L:16D) photoperiod had the lowest feed consumption compared to other two photoperiods (long/continuous (23L:1D), regular/intermittent (2L:2D)), broilers reared under short/non-intermittent photoperiod had reduced feed intake on d 14, d 28, d 42, and d 56 of age compared with those subjected to long/continuous and regular/intermittent photoperiods . 
In studies of Schwean-Lardner et al., (2016), Yang et al., (2015) and Aviagen (2014), improved feed conversion efficiency was observed in birds subjected to split darkness when compared to the continuous light group. Intermittent feeding and lighting have been used to improve feed efficiency (Farghly and Hassanien, 2012; Farghly and Makled, 2015). lighting programs with moderate photoperiod include the best results of feed conversion due to energy conservation during rest periods (dark) (Liboni et al., 2013). Abbas et al., (2008) reported significantly better FCR, in birds exposed to intermittent light of 2L:2D when compared to the near continuous light group. Kheiri and Landy (2019) reported that feed conversion ratio of broiler chickens fed basal diet supplemented with $1-\alpha(\mathrm{OH}) \mathrm{D} 3$ and 1500 or $3000 \mathrm{IU}$ of cholecalciferol $/ \mathrm{kg}$ of diet were significantly better than those fed basal diet, basal diet supplemented with 1- $\alpha(\mathrm{OH}) \mathrm{D} 3$ alone or basal diet supplemented with 1- $\alpha(\mathrm{OH}) \mathrm{D} 3$ and $5000 \mathrm{IU}$ of cholecalciferol/ $\mathrm{kg}$ of diet. Cho et al., (2019) reported that at $14 \mathrm{D}, 31 \mathrm{D}$ and overall (0-31) FCR were not affected by dietary VD3 levels. Okafor and Kalio (2017) reported that feed conversion ratio of broilers was not significantly different due to the effect of vitamin D3 levels. Abbasi et al., (2017) reported that all experimental treatments did not influence feed conversion ratio and no significant differences were observed between treatments. Bozkurt et al., (2017) reported that feed conversion ratio was similar among dietary vitamin D3 treatments. Landy et al., (2015) reported that the supplementation of $5000 \mathrm{IU}$ cholecalciferol $/ \mathrm{kg}$ of diet contained $5 \mu \mathrm{g}$ of $1-\alpha(\mathrm{OH}) \mathrm{D} 3 / \mathrm{kg}$ of diet significantly decreased feed efficiency of broiler chickens during starter period. Khan et al., (2009) showed that feed efficiency (weight gain/feed intake) was significantly influenced by the treatments used at both 21 and 42 days of age. At both 21 and 42 days of age, the feed efficiency depressed significantly in broilers fed diet that had low level of VIT-D3 (200 IU $/ \mathrm{kg}$ ) compared with other which fed high levels of VIT D3 $(1500,2500$ or $3500 \mathrm{IU} / \mathrm{kg})$.

Olanrewaju et al., (2019) showed that broilers subjected to the short/non-intermittent photoperiod had the lowest carcass characteristics compared with values obtained for regular/ intermittent photoperiods. Farghly et al., (2019a) reported that the interaction between feeding regimes $\times$ lighting programs broilers subjected to a restricted feeding regime $\times$ flashing light had the lowest abdominal fat percentages of all the groups. Arowolo et al., (2019) reported that various degrees of intermittent photo-period (i.e. mixing photo and scoto - periods within 24 hours) rather than one continuous photoperiod have been proven to significantly improve broilers' carcass yield. Farghly et al., (2017) reported that light flashes program significantly improved carcass dressing percentage, breast percentage and abdominal fat percentage. Metwally et al., (2015) reported that light type significantly affected carcass traits. In studies of Schwean-Lardner et al., (2016). Olanrewaju et al., (2012) Indicated that long/continuous and regular/intermittent photoperiod equally improved broiler carcass characteristics compared with short/non-intermittent photoperiod. Farghly et al., (2019a) reported that lighting programs (100\% continuous light or 50\% continuous light and 50\% flashing light) did not significantly change the carcass traits. Also, changes were not observed in spleen percentage of the broilers reared under the different lighting programs. Farghly et al., (2017) reported that light flashes program has insignificant effect in drumstick, femur, liver, heart and gizzard .

Okafor and Kalio (2017) reported that there was a significant difference in the weight of the gizzards at the $80 \%$ and $100 \%$ inclusion levels. Birds fed 100\% inclusion levels of vitamin D3 in their diet had the highest carcass weight. Dietary 25 OH D3 supplementation has also been reported to improve breast meat yield as a result of increased muscle protein synthesis (Berri et al., 2013; Hutton et al., 2014; Vignale et al., 2015). Khan et al., (2010) showed that the dressing percentage and breast meat yield were better in birds fed diets containing 2500 or $3500 \mathrm{IU} / \mathrm{Kg}$ vitamin D3. Paul et al., (2010) reported that increased vitamin supplementation in broiler diets significantly improved carcass composition of broilers. Pesti and Shivaprasad (2010) reported that no gross lesions or abnormalities were observed in the heart, kidney, bursa of Fabricius, pancreas, eye, intestine, liver, spleen, lungs, or skin tissue of control birds or broilers fed $1 \alpha-$ OH-D3 at any level $(0,5,15$, and $25 \mu \mathrm{g} / \mathrm{kg}))$.

Therefore, the objective of this present study was to investigate the influence of lighting regimens and vitamin D3 levels on the growth performance and carcass measurements of broilers.

\section{MATERIALS AND METHODS}

The current study was carried out at the Research Poultry Farm, Faculty of Agriculture, Assiut University, Assiut, Egypt. 


\section{Management and experimental design}

270 broiler chicks, One-day old from a common commercial strain (Sasso). chicks were divided into 9 treatments 30 birds each in three replicates 10 birds each in a factorial design $(3 \times 3)$. Three light regimens were used, 24hr continues light (C), 12hr continues light plus $12 \mathrm{hr}$ flash light (CF) and 24hr flash light (F). Three levels of vitamin D3 were used (Control level one, 200 ICU level two and level three $400 \mathrm{ICU} / \mathrm{Kg}$ ). Based on the conversion of $0.025 \mu \mathrm{g}$ to 1 ICU NRC, 1994. Chicks were wing-banded, weighed and housed in 27 rectangular pens $\left(2 \mathrm{~m}^{2}\right)$ the stocking density was $10 \mathrm{birds} / \mathrm{m}^{2}$ on wheat straw litter floor with $6 \mathrm{Cm}$ deep situated in thermostatically controlled building to provide the required temperature. The chicks were reared under $32{ }^{\circ} \mathrm{C}$ temperature as standard brooding temperature and $55 \%$ relative humidity during the first week, then gradually reduced $2{ }^{\circ} \mathrm{C}$ every three days to reach $24{ }^{\circ} \mathrm{C}$ and $55 \%$ relative humidity. The pens were lightproof by using double-layer black curtains on the windows. The light and dark cycles were obtained by using test light source controlled by automatic timer and dimmer to justify lighting periods and light intensity between 5 and 10 lux for each lighting group. Light source was incandescent bulb. Light flashes defined as a twenty light flashes per minute and they were generated by a flasher device that contained a timer and dimmer to justify lighting periods and intensity. Each pen was equipped with a feeder and a drinker. Chicks were provided with as much food and water as they wanted, and feed consumption was calculated at the end of each week. Chicks were provided with commercial feed according to age specifications. All diets were formulated to meet or exceed NRC (1994) recommendations for essential amino acids in starter diet containing $(23 \%$ protein, ME $3000 \mathrm{Kcal} . / \mathrm{Kg}$ ) from day one to twenty-one days old of age and grower diet containing $(21 \%$ protein, ME $3100 \mathrm{Kcal} . / \mathrm{Kg})$ from twenty-two days to forty-two days old of age (NRC 1994). The design as follow:

Group one (G1): Chicks were exposed to $24 \mathrm{hr}$ of continues light and fed a diet with level one (zero international chick unit of vitamin D3) of vitamin D3.

Group two (G2): Chicks were exposed to $24 \mathrm{hr}$ of continues light and fed a diet with level two (200 international chick unit of vitamin D3) of vitamin D3.

Group three (G3): Chicks were exposed to $24 \mathrm{hr}$ hours of continues light and fed a diet with level three (400 international chick unit of vitamin D3) of vitamin D3.

Group four (G4): Chicks were exposed to $12 \mathrm{hr}$ continues light plus $12 \mathrm{hr}$ flash light and fed a diet with level one (zero international chick unit of vitamin D3) of vitamin D3.

Group five (G5): Chicks were exposed to $12 \mathrm{hr}$ continues light with $12 \mathrm{hr}$ flash light and fed a diet with level two (200 international chick unit of vitamin D3) of vitamin D3.

Group six (G6): Chicks were exposed to $12 \mathrm{hr}$ continues light with $12 \mathrm{hr}$ flash light and fed a diet with level three (400 international chick unit of vitamin D3) of vitamin D3.

Group seven (G7): Chicks were exposed to $24 \mathrm{hr}$ of flash light and fed a diet with level one (zero international chick unit of vitamin D3) of vitamin D3.

Group eight (G8): Chicks were exposed to 24hr of flash light and fed a diet with level two (200 international chick unit of vitamin D3) of vitamin D3.

Group nine (G9): Chicks were exposed to $24 \mathrm{hr}$ of flash light and fed a diet with level three (400 international chick unit of vitamin D3) of vitamin D3.

\section{Measured criteria}

Body weights were recorded at one-day old, one, two, three, four, five and six weeks of age. chicks were individually weighed ( \pm 1 gram). Body weight gains $(\mathrm{BWG})$ and feed conversion ratio (FCR) were calculated at (0-1), (1-2), (2-3), (3-4), (4-5) and (5-6) weeks of age. Feed consumption was determined and calculated as gram feed/bird/day for the same time periods. At the end of the experiment (6 weeks of age), 27 birds were randomly taken as representative samples 3 birds per group; one bird per replicate, the birds were individually weighed, slaughtered by cutting the neck near the first cervical vertebra and then blooded freely for 10 minutes, eviscerated to evaluate and to record carcass and measurements of the dressed carcass (carcass weight + giblets weight), edible viscera weight (Giblet $=$ liver, heart and gizzard), breast meat yield, thigh, abdominal fat as percentages of the preslaughter weight were also recorded. 


\section{Metwally et al.}

\section{Statistical analysis}

Data obtained from this study were tested for the significance of lighting treatments effect by ANOVA and GLM using the SAS procedure (version 9.2, 2009). Duncan's multiple range test (1955) was used to determine differences among means when treatment effects were significant. All data percentages of this study were transformed to Arcsine values before analysis. Significant differences were considered to exist when $(\mathrm{P}<0.05)$.

The mathematical model was as follows:

$$
\text { Yijk }=\mu+\mathbf{L i}+\mathbf{D j}+(\mathbf{L D}) \mathbf{i j}+\mathbf{E i j k}
$$

Where: Yijk $=$ any observation. $\mu=$ The population mean. $\mathrm{Li}=$ Lighting programs effect $(\mathrm{i}=1,2$ and 3$) . \mathrm{Dj}$ $=$ Vitamin D3 levels effect $(\mathrm{j}=1,2$ and 3). $(\mathrm{LD}) \mathrm{ij}=$ Interaction of lighting programs $\times$ vitamin D3 levels. Eijk $=$ Experimental error.

\section{RESULTS AND DISCUSSIONS}

\section{Body weight}

The results of body weight as affected by light regimens and vitamin D3 levels and their interactions presented in (Table 1). There were significant differences due to lighting programs at 3, 4, 5 and 6 weeks of age at $(\mathrm{P}<0.05)$. Body weight of Sasso broiler chicks which exposed to a continues+flash lighting program were the same significantly affect as the effect of flash lighting program they both were higher than continues lighting programs. Regarding to the effect of vitamin D3 levels, there were significant differences on body weight at $3,4,5$ and 6 weeks of age at $(\mathrm{P} \leq 0.05)$. There were insignificant effects at one-day old, one week and two weeks old of age. Chicks which fed on diet with vitamin D3 level 200IU/Kg were the same significantly affect as the effect of 400IU/Kg of Vit.D3 level so level 2 of Vit. D3 and level 3 is better than level one. There was significant affect due to the interaction between light program and vitamin D3 levels on body weight at all ages except the weights at one-day old, one week and two weeks old of age. Our results in agreement with Farghly et al., (2019a) reported that broilers exposed to flashing light had the highest body weight. Using flashing light may have aided early growth by providing more opportunity for the birds to reduce heat production and stimulate the secretory patterns of several hormones (Farghly and Makled, 2015; Farghly et al., 2016). Nelson et al., (2020) postulated that providing intermittent light with a short dawn/dusk period yielded heavier birds than did increasing day length with a long dawn/dusk period, probably because of differences in feeding behavior and physical activity. The obtained results are in agreement with others (Lien et al., 2007; Onbasilar et al., 2007). Lighting affects thyroid hormones and melatonin, which play major roles in growth and development (Zeman et al., 2004; Schwean-Lardner et al., 2016). Lien et al., (2007) proposed that the interaction of photoperiod is more influential on body weight than photoperiod alone .

In the contrast Bayram and Özkan (2010) reported that birds in the 16 L:8 D photoperiod treatment weighed less than those in the $24 \mathrm{~L}$ treatment at $3 \mathrm{wk}$ of age $(\mathrm{P} \leq 0.05)$ but were similar again by 6 wk of age. Body weights of broilers in the 16L:8D group reached those of broilers in the 24L group at slaughter age. Therefore, final BW were not affected by lighting treatment under the experimental conditions. Also, Lien et al., (2007) reported that there were interaction effects on BW at 29, 43, and $49 \mathrm{~d}$. At $29 \mathrm{~d}$, both $18 \mathrm{~L}$ and 0.1FC (Foot Candle) treatments reduced BW. This effect was not only due to the increase in photoperiod from 18L:6D to 23L:1D during the last $6 \mathrm{~d}$ in the 18L treatment, because it was already underway at $43 \mathrm{~d}$ and occurred in the $0.1 \mathrm{FC}-18 \mathrm{~L}$ but not the $1 \mathrm{FC}-18 \mathrm{~L}$ treatment.

Reversely with Han et al., (2009) who reported that supplementation of $5 \mu \mathrm{g} 1-\alpha(\mathrm{OH}) \mathrm{D} 3 / \mathrm{kg}$ to broiler chicken diet containing $5 \mu \mathrm{g}$ cholecalciferol $/ \mathrm{kg}$ had negative effects on BW of broiler chickens, which 
Egyptian J. Nutrition and Feeds (2021)

Table (1): Effects of lighting programs, vitamin D3 levels and their interactions on body weights (g) of broiler chicks.

\begin{tabular}{|c|c|c|c|c|c|c|c|}
\hline \multirow[t]{2}{*}{ Age (Weeks) Treatments } & \multicolumn{7}{|c|}{ Age (weeks) } \\
\hline & 1 day old & 1 & 2 & 3 & 4 & 5 & 6 \\
\hline \multicolumn{8}{|l|}{ Lighting programs: } \\
\hline Continues (C) & $39.03 \pm 0.19$ & $100.88 \pm 0.58$ & $363.21 \pm 2.98$ & $623.39 \pm 5.18^{\mathrm{b}}$ & $868.02 \pm 11.02^{\mathrm{b}}$ & $1048.41 \pm 9.81^{\mathrm{b}}$ & $1231.61 \pm 10.52^{b}$ \\
\hline Continues+Flash (CF) & $39.37 \pm 0.24$ & $99.24 \pm 0.79$ & $359.31 \pm 3.15$ & $673.69 \pm 6.24^{\mathrm{a}}$ & $937.17 \pm 9.37^{\mathrm{a}}$ & $1124.72 \pm 8.39^{\mathrm{a}}$ & $1329.00 \pm 7.22^{\mathrm{a}}$ \\
\hline Flash $(F)$ & $39.15 \pm 0.28$ & $99.74 \pm 0.60$ & $358.04 \pm 2.31$ & $663.36 \pm 6.48^{\mathrm{a}}$ & $918.06 \pm 8.33^{\mathrm{a}}$ & $1111.14 \pm 7.76^{\mathrm{a}}$ & $1316.98 \pm 8.93^{\mathrm{a}}$ \\
\hline$P$-value & 0.6095 & 0.2010 & 0.4070 & $<.0001$ & $<.0001$ & $<.0001$ & $<.0001$ \\
\hline \multicolumn{8}{|l|}{ Vit. D3 levels: } \\
\hline Control level 1 (L1) & $39.32 \pm 0.22$ & $99.34 \pm 0.59$ & $361.16 \pm 3.37$ & $623.83 \pm 5.74^{\mathrm{b}}$ & $854.03 \pm 9.78^{\mathrm{b}}$ & $1064.08 \pm 11.21^{\mathrm{b}}$ & $1261.75 \pm 11.35^{\mathrm{b}}$ \\
\hline 200 IU level 2 (L2) & $39.37 \pm 0.24$ & $100.08 \pm 0.83$ & $358.02 \pm 2.62$ & $668.39 \pm 6.36^{\mathrm{a}}$ & $943.46 \pm 8.90^{\mathrm{a}}$ & $1102.02 \pm 7.30^{\mathrm{a}}$ & $1303.57 \pm 10.07^{\mathrm{a}}$ \\
\hline 400 IU level 3 (L3) & $38.87 \pm 0.26$ & $100.44 \pm 0.54$ & $361.38 \pm 2.46$ & $668.22 \pm 5.95^{\mathrm{a}}$ & $925.17 \pm 9.13^{\mathrm{a}}$ & $1117.89 \pm 8.38^{\mathrm{a}}$ & $1311.13 \pm 8.19^{\mathrm{a}}$ \\
\hline$P$-value & 0.2681 & 0.4917 & 0.6468 & $<.0001$ & $<.0001$ & 0.0001 & 0.0012 \\
\hline \multicolumn{8}{|l|}{ Interactions: } \\
\hline$(\mathrm{G} 1) \mathrm{C}^{*} \mathrm{~L} 1$ & $39.00 \pm 0.38$ & $100.52 \pm 0.87$ & $368.83 \pm 6.37$ & $593.00 \pm 8.78^{\mathrm{c}}$ & $785.47 \pm 15.91^{\mathrm{e}}$ & $1010.89 \pm 23.77^{\mathrm{d}}$ & $1188.54 \pm 20.10^{\mathrm{d}}$ \\
\hline$(\mathrm{G} 2) \mathrm{C}^{*} \mathrm{~L} 2$ & $39.03 \pm 0.32$ & $100.97 \pm 1.13$ & $356.40 \pm 5.66$ & $633.83 \pm 8.19^{\mathrm{b}}$ & $914.17 \pm 18.63^{\mathrm{bcd}}$ & $1071.50 \pm 14.13^{\mathrm{c}}$ & $1241.62 \pm 21.53^{\mathrm{c}}$ \\
\hline (G3) C*L3 & $39.07 \pm 0.32$ & $101.17 \pm 1.01$ & $364.40 \pm 2.47$ & $643.33 \pm 7.29^{\mathrm{b}}$ & $901.67 \pm 13.09^{\mathrm{cd}}$ & $1060.33 \pm 9.36^{c}$ & $1255.76 \pm 9.52^{c}$ \\
\hline (G4) $\mathrm{CF}^{*} \mathrm{~L} 1$ & $39.30 \pm 0.40$ & $98.30 \pm 1.22$ & $359.93 \pm 5.17$ & $648.75 \pm 8.90^{\mathrm{b}}$ & $880.50 \pm 12.28^{\mathrm{d}}$ & $1089.33 \pm 16.80^{\mathrm{bc}}$ & $1304.00 \pm 14.39^{\mathrm{ab}}$ \\
\hline (G5) $\mathrm{CF}^{*} \mathrm{~L} 2$ & $39.83 \pm 0.46$ & $99.73 \pm 1.96$ & $363.33 \pm 4.61$ & $693.33 \pm 10.48^{\mathrm{a}}$ & $978.67 \pm 12.78^{\mathrm{a}}$ & $1117.33 \pm 9.95^{\mathrm{b}}$ & $1333.83 \pm 10.77^{\mathrm{a}}$ \\
\hline (G6) CF*L3 & $38.97 \pm 0.39$ & $99.70 \pm 0.55$ & $354.67 \pm 6.50$ & $679.00 \pm 11.58^{\mathrm{a}}$ & $952.33 \pm 17.79^{\mathrm{ab}}$ & $1167.50 \pm 12.61^{\mathrm{a}}$ & $1345.00 \pm 11.90^{\mathrm{a}}$ \\
\hline (G7) F*L1 & $39.65 \pm 0.40$ & $99.22 \pm 0.92$ & $354.72 \pm 5.78$ & $629.75 \pm 9.58^{\mathrm{b}}$ & $895.21 \pm 15.23^{\mathrm{cd}}$ & $1089.31 \pm 13.65^{b c}$ & $1284.16 \pm 17.19^{b c}$ \\
\hline (G8) F*L2 & $39.23 \pm 0.44$ & $99.53 \pm 1.09$ & $354.33 \pm 2.87$ & $678.00 \pm 11.40^{\mathrm{a}}$ & $937.34 \pm 11.75^{\mathrm{abc}}$ & $1117.76 \pm 11.90^{\mathrm{b}}$ & $1334.21 \pm 12.79^{\mathrm{a}}$ \\
\hline (G9) $F^{*} \mathrm{~L} 3$ & $38.57 \pm 0.59$ & $100.47 \pm 1.13$ & $365.07 \pm 2.25$ & $682.33 \pm 10.32^{\mathrm{a}}$ & $921.50 \pm 15.34^{\mathrm{bcd}}$ & $1125.83 \pm 14.12^{b}$ & $1331.45 \pm 14.95^{\mathrm{a}}$ \\
\hline$P$-value & 0.5750 & 0.7588 & 0.2835 & $<.0001$ & $<.0001$ & $<.0001$ & $<.0001$ \\
\hline
\end{tabular}


indicated that $1-\alpha(\mathrm{OH}) \mathrm{D} 3$, could not enhance growth performance indices of broiler chickens when basal diet contained adequate content of cholecalciferol.

\section{Body weight gain}

The results of body weight gain as affected by light regimens and vitamin D3 levels and their interactions presented in (Table 2). There were significant differences due to lighting programs at three, six and the mean gain weeks of age at $(\mathrm{P} \leq 0.05)$. There were no significant differences at $1,2,4$, and 5 weeks of age as affected by lighting programs. However, body weight gains of Sasso broiler chicks which exposed to the continues + flash lighting program were better than the other both continues and flash lighting programs. There were significant effects due to vitamin D3 levels at 3, 4, 5, and the mean gain of weeks of age at $(\mathrm{P} \leq 0.05)$. There were no significant differences at the first, second and sixth weeks of age as affected by vitamin D3 levels. However, broilers that had fed on diet with level two of vitamin D3 was significantly equaled with level three of vitamin D3 in the mean gain weeks of age, and they both were higher than the chicks which fed on level one of vitamin D3. There were significant effects due to the interaction between lighting programs and vitamin D3 levels on body weight gain at all ages except the first and second weeks of age. These results are in equal with Farghly et al., (2019a) reported that broilers exposed to flashing light regime had the highest BWG .

Reversely, Bayram and Özkan (2010) who reported that the mean daily BW gain of broilers from 3 to 6 wk was 89.7 $\mathrm{g} / \mathrm{d}$ in the 16L:8D group and $86.6 \mathrm{~g} / \mathrm{d}$ in the $24 \mathrm{~L}$ group. In this study, a constant photoperiod (16 L:8 D) beginning at $2 \mathrm{~d}$ of age reduced early growth, leading to a decrease in BW at 3 wk and in BW gain between 0 and 3 wk compared with broilers reared under the $24 \mathrm{~L}$ photoperiod .

Same results with Cho et al., (2019) reported that at $14 \mathrm{D}$, the effect of dietary V D3 levels on body weight gain was mathematically significant between the groups that received V D3 $200 \mathrm{IU} / \mathrm{kg}$ of feed and 3,125 IU/kg of feed, and the highest weight gain was observed in birds fed with V D3 at 3,125 IU/kg of feed. Increasing VD3 from $300 \mathrm{IU} / \mathrm{kg}$ to 1,200 IU/kg improved BW gain in broilers at 17 D and 35 D (Ramo Rao et al., 2009). Also. Khan et al., (2009) showed that maximum body weight was gained by supplementing 1500 to $3500 \mathrm{IU} / \mathrm{kg}$ of VIT-D3. The major circulating form of vitamin D3, 25-hydroxycholecalciferol (25 OH D3), has been shown to improve body weight (BW) gain (Garcia et al., 2013) .

\section{Feed consumption}

The results of feed consumption as affected by light regimens and vitamin D3 levels and their interactions presented in (Table 3). There were no significant differences due to lighting programs on feed consumption at all ages. However, feed consumption of Sasso broiler chicks which exposed to the flash lighting program were lower consumption than the other both lighting programs numerically. Regarding with the effect of vitamin D3 levels, there were no significant differences on feed consumption at all ages. There were insignificant effects due to the interactions between light programs and vitamin D3 levels on feed consumption at all ages. Same results like Farghly et al., (2019b) who reported that no significant effect on feed consumption due to lighting programs. Also, Bayram and Özkan (2010) who reported that total feed consumption was 3.44 and $3.31 \mathrm{~kg} / \mathrm{bird}$ for birds in the $16 \mathrm{~L}: 8 \mathrm{D}$ and control group, respectively, and there was no difference between groups .

Reversely, Amakiri et al., (2011) revealed that birds on restricted light regimens can maintain a FC similar to those under continuous illumination by increasing their rate of consumption per unit of illumination time. Sun et al., (2017) reported that during the finishing stage (d 56-91), the average daily feed intake (ADFI) of broiler chickens under 16L:8D regimen was greater than those of other regimens.

Same result with, Adhikari et al., (2020) showed that there was no difference in FI between hens fed diets supplemented with different levels of vitamin D3 and 25-OHD. Kheiri and Landy (2019) who stated that in starter period, there were no significant differences between vitamin D3 dietary treatments for daily feed intake (DFI).

Reversely, Adhikari et al., (2020) showed that hens fed the diet supplemented with 3,000 IU of vitamin D2 had significantly higher $(\mathrm{P}<0.05)$ FI compared to hens fed the diet supplemented with 9,000 IU. And, Han et al., (2009) who reported that supplementation of $5 \mu \mathrm{g} 1-\alpha(\mathrm{OH}) \mathrm{D} 3 / \mathrm{kg}$ to broiler chicken diet containing $5 \mu \mathrm{g}$ cholecalciferol $/ \mathrm{kg}$ had negative effects on DFI of broiler chickens.

\section{Feed conversion ratio}

The results of feed conversion ratio as affected by light regimens and vitamin D3 levels and their interactions presented in (Table 4). There were significant differences due to lighting programs at the intervals between (2-3), the mean FCR and total weeks of age at $(\mathrm{P} \leq 0.05)$. However, feed conversion ratio of Sasso broiler chicks which exposed to a flash lighting and continues+flash lighting programs were the best lighting program. The rest of the other ages had no significant effects. Chicks which fed on diet with level 2 and 3 of vitamin D3 were the same significantly effect. Level 2 and 3 of Vit. D3 was better than the level 1. While, the rest of the other ages had no significant effects. The groups were raised under the continues + flash lighting program, flash program and fed on diet with level two and three of vitamin D3 were better than the other treatments. Our study in agreement with Farghly et al., (2019a) who reported that broilers 
Egyptian J. Nutrition and Feeds (2021)

Table (2): Effects of lighting programs, vitamin D3 levels and their interactions on body weight gain (g) of broiler chicks.

\begin{tabular}{|c|c|c|c|c|c|c|c|c|}
\hline \multirow{2}{*}{$\begin{array}{l}\text { Age (Weeks) } \\
\text { Treatments }\end{array}$} & \multicolumn{8}{|c|}{ Age (weeks) } \\
\hline & 1 & 2 & 3 & 4 & 5 & 6 & Mean & $1-6$ \\
\hline \multicolumn{9}{|l|}{ Lighting programs: } \\
\hline Continues (C) & $8.84 \pm 0.07$ & $37.48 \pm 0.41$ & $37.17 \pm 0.65^{\mathrm{b}}$ & $34.79 \pm 1.14$ & $26.78 \pm 1.26$ & $25.75 \pm 0.93^{\mathrm{b}}$ & $28.58 \pm 0.31^{\mathrm{b}}$ & $1144.06 \pm 17.38^{\mathrm{b}}$ \\
\hline Continues+Flash (CF) & $8.55 \pm 0.10$ & $37.15 \pm 0.44$ & $44.91 \pm 0.88^{\mathrm{a}}$ & $37.64 \pm 1.02$ & $26.79 \pm 1.19$ & $28.42 \pm 0.98^{\mathrm{a}}$ & $30.58 \pm 0.20^{\mathrm{a}}$ & $1273.22 \pm 10.47^{\mathrm{a}}$ \\
\hline Flash (F) & $8.66 \pm 0.09$ & $36.90 \pm 0.35$ & $43.62 \pm 0.93^{\mathrm{a}}$ & $36.50 \pm 0.92$ & $27.58 \pm 1.15$ & $29.14 \pm 0.86^{\mathrm{a}}$ & $30.40 \pm 0.21^{\mathrm{a}}$ & $1257.72 \pm 13.56^{\mathrm{a}}$ \\
\hline$P$-value & 0.0758 & 0.5940 & $<.0001$ & 0.1438 & 0.8618 & 0.0290 & $<.0001$ & $<.0001$ \\
\hline \multicolumn{9}{|l|}{ Vit. D3 levels: } \\
\hline Control level 1 (L1) & $8.58 \pm 0.08$ & $37.40 \pm 0.49$ & $37.52 \pm 0.84^{\mathrm{b}}$ & $32.90 \pm 0.85^{\mathrm{b}}$ & $30.09 \pm 0.93^{\mathrm{a}}$ & $26.71 \pm 0.78$ & $28.83 \pm 0.30^{\mathrm{b}}$ & $1168.89 \pm 18.56^{\mathrm{b}}$ \\
\hline 200 IU level 2 (L2) & $8.67 \pm 0.10$ & $36.85 \pm 0.34$ & $44.34 \pm 0.80^{\mathrm{a}}$ & $39.29 \pm 1.02^{\mathrm{a}}$ & $23.40 \pm 1.30^{\mathrm{b}}$ & $29.46 \pm 1.11$ & $30.48 \pm 0.24^{\mathrm{a}}$ & $1239.92 \pm 14.94^{\mathrm{a}}$ \\
\hline 400 IU level 3 (L3) & $8.80 \pm 0.08$ & $37.28 \pm 0.35$ & $43.83 \pm 0.88^{\mathrm{a}}$ & $36.71 \pm 1.11^{\mathrm{a}}$ & $27.53 \pm 1.22^{\mathrm{b}}$ & $27.34 \pm 0.84$ & $30.25 \pm 0.19^{\mathrm{a}}$ & $1266.18 \pm 9.09^{\mathrm{a}}$ \\
\hline$P$-value & 0.2114 & 0.5908 & $<.0001$ & $<.0001$ & 0.0003 & 0.0956 & $<.0001$ & $<.0001$ \\
\hline (G1) C*L1 & $8.79 \pm 0.11$ & $38.33 \pm 0.89$ & $32.02 \pm 1.04^{\mathrm{c}}$ & $27.15 \pm 1.24^{\mathrm{d}}$ & $32.92 \pm 1.55^{\mathrm{a}}$ & $23.02 \pm 1.33^{\mathrm{c}}$ & $26.93 \pm 0.55^{\mathrm{d}}$ & $1068.67 \pm 37.61^{\mathrm{d}}$ \\
\hline (G2) C*L2 & $8.85 \pm 0.14$ & $36.49 \pm 0.75$ & $39.63 \pm 0.77^{\mathrm{b}}$ & $40.05 \pm 2.12^{\mathrm{a}}$ & $25.01 \pm 2.64^{\mathrm{bcd}}$ & $25.71 \pm 2.06^{\mathrm{bc}}$ & $29.84 \pm 0.61^{\mathrm{bc}}$ & $1153.17 \pm 29.81^{\mathrm{c}}$ \\
\hline (G3) C*L3 & $8.87 \pm 0.13$ & $37.60 \pm 0.32$ & $39.85 \pm 0.89^{\mathrm{b}}$ & $36.90 \pm 1.61^{\mathrm{abc}}$ & $22.67 \pm 1.89^{\mathrm{cd}}$ & $27.94 \pm 1.31^{\mathrm{ab}}$ & $28.98 \pm 0.22^{\mathrm{c}}$ & $1210.33 \pm 11.28^{\mathrm{bc}}$ \\
\hline (G4) $\mathrm{CF}^{*} \mathrm{~L} 1$ & $8.43 \pm 0.17$ & $37.38 \pm 0.75$ & $41.26 \pm 1.03^{\mathrm{b}}$ & $33.11 \pm 1.16^{\mathrm{c}}$ & $29.83 \pm 1.44^{\mathrm{ab}}$ & $29.07 \pm 1.49^{\mathrm{ab}}$ & $29.83 \pm 0.43^{b c}$ & $1219.62 \pm 24.48^{b c}$ \\
\hline (G5) $\mathrm{CF}^{*} \mathrm{~L} 2$ & $8.56 \pm 0.22$ & $37.66 \pm 0.56$ & $47.14 \pm 1.39^{\mathrm{a}}$ & $40.76 \pm 1.70^{\mathrm{a}}$ & $19.81 \pm 1.77^{\mathrm{d}}$ & $30.93 \pm 1.84^{\mathrm{a}}$ & $30.81 \pm 0.26^{\mathrm{ab}}$ & $1294.00 \pm 10.82^{\mathrm{a}}$ \\
\hline (G6) $\mathrm{CF}^{*} \mathrm{~L} 3$ & $8.68 \pm 0.09$ & $36.42 \pm 0.93$ & $46.33 \pm 1.86^{\mathrm{a}}$ & $39.05 \pm 2.08^{\mathrm{ab}}$ & $30.74 \pm 2.28^{\mathrm{ab}}$ & $25.36 \pm 1.54^{\mathrm{bc}}$ & $31.10 \pm 0.28^{\mathrm{a}}$ & $1306.03 \pm 11.87^{\mathrm{a}}$ \\
\hline$(\mathrm{G} 7) \mathrm{F}^{*} \mathrm{~L} 1$ & $8.51 \pm 0.13$ & $36.50 \pm 0.88$ & $39.29 \pm 1.66^{\mathrm{b}}$ & $38.44 \pm 1.24^{\mathrm{ab}}$ & $27.73 \pm 1.73^{\mathrm{abc}}$ & $27.64 \pm 1.01^{\mathrm{abc}}$ & $29.72 \pm 0.39^{b c}$ & $1218.40 \pm 25.23^{b c}$ \\
\hline$(\mathrm{G} 8) \mathrm{F}^{*} \mathrm{~L} 2$ & $8.61 \pm 0.14$ & $36.40 \pm 0.41$ & $46.24 \pm 1.47^{\mathrm{a}}$ & $36.98 \pm 1.35^{\mathrm{abc}}$ & $25.77 \pm 2.32^{\mathrm{bc}}$ & $30.92 \pm 1.81^{\mathrm{a}}$ & $30.80 \pm 0.30^{\mathrm{ab}}$ & $1272.60 \pm 25.52^{\mathrm{ab}}$ \\
\hline (G9) $\mathrm{F}^{*} \mathrm{~L} 3$ & $8.84 \pm 0.20$ & $37.80 \pm 0.36$ & $45.32 \pm 1.44^{\mathrm{a}}$ & $34.17 \pm 1.98^{\mathrm{bc}}$ & $29.19 \pm 1.91^{\mathrm{ab}}$ & $28.80 \pm 1.48^{\mathrm{ab}}$ & $30.68 \pm 0.36^{\mathrm{ab}}$ & $1282.17 \pm 17.95^{\mathrm{ab}}$ \\
\hline $\mathrm{P}$-value & 0.3400 & 0.3463 & $<.0001$ & $<.0001$ & $<.0001$ & 0.0076 & $<.0001$ & $<.0001$ \\
\hline
\end{tabular}


Egyptian J. Nutrition and Feeds (2021), 24(1): 171-185

Table (3): Effects of lighting programs, vitamin D3 levels and their interactions on feed consumption (g/b/d) of broiler chicks.

\section{Age (Weeks) Treatments}

Lighting programs:

Continues (C)

Continues+Flash $(\mathrm{CF})$

Flash (F)

$P$-value

Vit. D3 levels:

Control level 1 (L1)

200 IU level 2 (L2)

400 IU level 3 (L3)

$P$ - value

Interactions:

(G1) C*L1

(G2) $\mathrm{C}^{*} \mathrm{~L} 2$

(G3) C*L3

(G4) $\mathrm{CF}^{*} \mathrm{~L} 1$

(G5) $\mathrm{CF}^{*} \mathrm{~L} 2$

(G6) $\mathrm{CF}^{*} \mathrm{~L} 3$

(G7) $F^{*} \mathrm{~L} 1$

(G8) $\mathrm{F}^{* \mathrm{~L} 2}$

(G9) F*L3

$P$-value

\section{$0-1 \quad 1-2 \quad 2-3$}

$3-4$

Age (weeks)

$18.22+0.40$

\section{$18.27 \pm 0.43$}

$8.32 \pm 0.39$

0.9849

$46.67 \pm 0.83$

$46.44 \pm 0.82$

$46.21 \pm 0.67$

$51.31 \pm 1.87$

$51.29 \pm 1.57$

$50.74 \pm 0.92$

0.9178

0.9556

$18.33 \pm 0.48$

$18.28 \pm 0.27$

$18.20 \pm 0.44$

0.9732

$47.24 \pm 1.07$

$46.19 \pm 0.47$

$52.97 \pm 1.53$

$50.23 \pm 1.44$

$50.14 \pm 1.32$

0.4207

0.3044

$17.50 \pm 0.29$

$18.33 \pm 0.60$

$18.83 \pm 1.01$

$19.00 \pm 1.15$

$17.97 \pm 0.26$

$17.83 \pm 0.60$

$18.50 \pm 0.87$

$18.53 \pm 0.58$

$17.93 \pm 0.81$

$47.83 \pm 2.17$

$53.13 \pm 3.22$

$46.00 \pm 1.04$

$51.97 \pm 4.23$

$46.17 \pm 1.20$

$48.83 \pm 2.95$

$52.77 \pm 4.15$

$49.50 \pm 1.65$

$46.33 \pm 0.67$

$45.67 \pm 1.20$

$51.60 \pm 2.61$

$46.57 \pm 1.79$

$53.00 \pm 0.75$

$49.23 \pm 1.45$

$50.00 \pm 1.86$

0.8784
$46.23 \pm 1.03$

0.9802
4-5
$56.81 \pm 1.60$

$51.89 \pm 2.16$

$51.57 \pm 1.41$

0.0801

$55.03 \pm 1.46$

$53.70 \pm 2.42$

$51.53 \pm 1.61$

0.4267

$55.50 \pm 1.44$

$61.43 \pm 2.25$

$53.50 \pm 2.60$

$55.50 \pm 4.33$

$49.50 \pm 4.27$

$50.67 \pm 2.96$

$54.10 \pm 2.06$

$50.17 \pm 1.42$

$50.43 \pm 3.58$

0.1784
$5-6$

Mean

$1-6$

All values were not significant in each classification $(P \leq 0.05)$.

\section{$58.81 \pm 1.60 \quad 77.66 \pm 0.75 \quad 51.58 \pm 0.66$}

$56.89 \pm 2.16 \quad 77.07 \pm 0.51 \quad 50.31 \pm 1.03$

$53.57 \pm 1.41 \quad 76.50 \pm 0.67$

0.1231

0.4644

$49 \pm 0.48$

$58.03 \pm 1.58 \quad 77.79 \pm 0.68$

$56.70 \pm 2.25 \quad 77.13 \pm 0.48$

$54.53 \pm 1.62 \quad 76.30 \pm 0.72$

$0.4132 \quad 0.2703$

$57.50 \pm 1.44 \quad 78.70 \pm 1.30$

$55.50 \pm 2.60 \quad 76.50 \pm 1.81$

$60.50 \pm 4.33 \quad 77.67 \pm 0.88$

$54.50 \pm 4.27 \quad 76.20 \pm 0.99$

$55.67 \pm 2.96 \quad 77.33 \pm 0.88$

$56.10 \pm 2.06 \quad 77.00 \pm 1.53$

$52.17 \pm 1.42 \quad 77.43 \pm 0.72$

$52.43+3.58 \quad 75.07 \pm 0.93$

$0.2196 \quad 0.5800$

0.1794

$51.57 \pm 0.77$

$50.37 \pm 0.91$

$49.43+0.55$

0.1569

$51.69 \pm 0.49$

$53.16 \pm 0.97$

$49.89 \pm 1.15$

$52.13 \pm 2.41$

$49.00 \pm 1.72$

$49.79 \pm 1.13$

$50.88 \pm 0.79$

$48.96 \pm 0.39$

$48.62 \pm 0.73$

$2166.34 \pm 27.53$

$2112.91 \pm 43.19$

$2078.38 \pm 20.26$

0.1652

$2165.80 \pm 32.26$

$2115.63 \pm 38.04$

$2076.20 \pm 23.06$

0.1569

$2171.17 \pm 20.41$

$2232.53 \pm 40.53$

$2095.33 \pm 48.09$

$2189.37 \pm 101.25$

$2058.00 \pm 72.17$

$2091.37 \pm 47.51$

$2136.87 \pm 33.37$

$2056.37 \pm 16.35$

$2041.90 \pm 30.45$

0.1794
$63.43 \pm 2.25 \quad 77.77 \pm 0.73$ 
Egyptian J. Nutrition and Feeds (2021)

Table (4): Effects of lighting programs, vitamin D3 levels and their interactions on feed conversion ratio (gain feed/ gain w eight) of broiler chicks.

\begin{tabular}{|c|c|c|c|c|c|c|c|c|}
\hline \multirow{2}{*}{$\begin{array}{l}\text { Age (Weeks) } \\
\text { Treatments }\end{array}$} & \multicolumn{8}{|c|}{ Age (weeks) } \\
\hline & $0-1$ & $1-2$ & $2-3$ & $3-4$ & $4-5$ & $5-6$ & Mean & $1-6$ \\
\hline \multicolumn{9}{|l|}{ Lighting programs: } \\
\hline Continues (C) & $2.06 \pm 0.04$ & $1.25 \pm 0.02$ & $1.40 \pm 0.09^{\mathrm{a}}$ & $1.68 \pm 0.10$ & $2.32 \pm 0.21$ & $3.14 \pm 0.19$ & $1.81 \pm 0.03^{\mathrm{a}}$ & $1.90 \pm 0.05^{\mathrm{a}}$ \\
\hline Continues+Flash $(\mathrm{CF})$ & $2.14 \pm 0.05$ & $1.25 \pm 0.02$ & $1.15 \pm 0.05^{\mathrm{b}}$ & $1.42 \pm 0.11$ & $2.24 \pm 0.18$ & $2.76 \pm 0.13$ & $1.65 \pm 0.04^{\mathrm{b}}$ & $1.66 \pm 0.05^{\mathrm{b}}$ \\
\hline Flash (F) & $2.12 \pm 0.05$ & $1.25 \pm 0.03$ & $1.17 \pm 0.05^{\mathrm{b}}$ & $1.42 \pm 0.06$ & $1.96 \pm 0.08$ & $2.67 \pm 0.10$ & $1.63 \pm 0.03^{\mathrm{b}}$ & $1.65 \pm 0.03^{\mathrm{b}}$ \\
\hline$P$-value & 0.5540 & 0.9706 & 0.0199 & 0.0902 & 0.2805 & 0.0708 & 0.0014 & 0.0006 \\
\hline \multicolumn{9}{|l|}{ Vit. D3 levels: } \\
\hline Control level 1 (L1) & $2.14 \pm 0.06$ & $1.26 \pm 0.03$ & $1.43 \pm 0.08^{\mathrm{a}}$ & $1.72 \pm 0.12^{\mathrm{a}}$ & $1.94 \pm 0.05^{\mathrm{b}}$ & $2.98 \pm 0.14$ & $1.79 \pm 0.04^{\mathrm{a}}$ & $1.86 \pm 0.05^{\mathrm{a}}$ \\
\hline 200 IU level 2 (L2) & $2.11 \pm 0.04$ & $1.25 \pm 0.02$ & $1.14 \pm 0.05^{\mathrm{b}}$ & $1.38 \pm 0.06^{\mathrm{b}}$ & $2.49 \pm 0.17^{\mathrm{a}}$ & $2.78 \pm 0.22$ & $1.65 \pm 0.04^{\mathrm{b}}$ & $1.72 \pm 0.07^{\mathrm{ab}}$ \\
\hline 400 IU level 3 (L3) & $2.07 \pm 0.05$ & $1.23 \pm 0.02$ & $1.15 \pm 0.04^{\mathrm{b}}$ & $1.43 \pm 0.07^{\mathrm{b}}$ & $2.09 \pm 0.19^{\mathrm{ab}}$ & $2.81 \pm 0.08$ & $1.64 \pm 0.03^{\mathrm{b}}$ & $1.64 \pm 0.03^{\mathrm{b}}$ \\
\hline$P$-value & 0.6302 & 0.6043 & 0.0029 & 0.0206 & 0.0429 & 0.6342 & 0.0092 & 0.0167 \\
\hline \multicolumn{9}{|l|}{ Interactions: } \\
\hline (G1) $C^{*} \mathrm{~L} 1$ & $1.99 \pm 0.06$ & $1.25 \pm 0.05$ & $1.66 \pm 0.13^{\mathrm{a}}$ & $2.04 \pm 0.04^{\mathrm{a}}$ & $1.76 \pm 0.10^{\mathrm{b}}$ & $3.43 \pm 0.11$ & $1.92 \pm 0.04^{\mathrm{a}}$ & $2.03 \pm 0.03^{\mathrm{a}}$ \\
\hline$(\mathrm{G} 2) \mathrm{C}^{*} \mathrm{~L} 2$ & $2.07 \pm 0.06$ & $1.26 \pm 0.04$ & $1.31 \pm 0.12^{\mathrm{bc}}$ & $1.55 \pm 0.08^{\mathrm{bc}}$ & $2.68 \pm 0.37^{\mathrm{a}}$ & $3.26 \pm 0.54$ & $1.78 \pm 0.03^{\mathrm{b}}$ & $1.94 \pm 0.09^{\mathrm{ab}}$ \\
\hline (G3) $C^{*} \mathrm{~L} 3$ & $2.12 \pm 0.11$ & $1.23 \pm 0.04$ & $1.23 \pm 0.11^{\mathrm{bc}}$ & $1.46 \pm 0.11^{\mathrm{bc}}$ & $2.52 \pm 0.35^{\mathrm{ab}}$ & $2.74 \pm 0.06$ & $1.72 \pm 0.03^{\mathrm{bc}}$ & $1.73 \pm 0.03^{\mathrm{cd}}$ \\
\hline (G4) $\mathrm{CF}^{*} \mathrm{~L} 1$ & $2.25 \pm 0.11$ & $1.27 \pm 0.05$ & $1.28 \pm 0.11^{\mathrm{bc}}$ & $1.71 \pm 0.24^{\mathrm{ab}}$ & $2.03 \pm 0.02^{\mathrm{ab}}$ & $2.73 \pm 0.29$ & $1.75 \pm 0.08^{\mathrm{b}}$ & $1.80 \pm 0.09^{\mathrm{bc}}$ \\
\hline (G5) $\mathrm{CF}^{*} \mathrm{~L} 2$ & $2.10 \pm 0.08$ & $1.23 \pm 0.02$ & $1.05 \pm 0.02^{\mathrm{c}}$ & $1.22 \pm 0.12^{\mathrm{c}}$ & $2.75 \pm 0.17^{\mathrm{a}}$ & $2.50 \pm 0.20$ & $1.59 \pm 0.04^{\mathrm{c}}$ & $1.59 \pm 0.04^{\mathrm{d}}$ \\
\hline (G6) $\mathrm{CF}^{*} \mathrm{~L} 3$ & $2.05 \pm 0.06$ & $1.26 \pm 0.03$ & $1.12 \pm 0.03^{\mathrm{bc}}$ & $1.33 \pm 0.12^{\mathrm{bc}}$ & $1.95 \pm 0.40^{\mathrm{ab}}$ & $3.06 \pm 0.08$ & $1.60 \pm 0.04^{\mathrm{c}}$ & $1.60 \pm 0.04^{\mathrm{d}}$ \\
\hline (G7) $F^{*} \mathrm{~L} 1$ & $2.17 \pm 0.07$ & $1.28 \pm 0.08$ & $1.35 \pm 0.04^{\mathrm{b}}$ & $1.41 \pm 0.12^{\mathrm{bc}}$ & $2.02 \pm 0.04^{\mathrm{ab}}$ & $2.79 \pm 0.06$ & $1.71 \pm 0.04^{\mathrm{bc}}$ & $1.75 \pm 0.01^{\mathrm{cd}}$ \\
\hline (G8) $F^{*} L 2$ & $2.15 \pm 0.10$ & $1.27 \pm 0.02$ & $1.07 \pm 0.01^{\mathrm{c}}$ & $1.36 \pm 0.03^{b c}$ & $2.05 \pm 0.24^{\mathrm{ab}}$ & $2.59 \pm 0.30$ & $1.59 \pm 0.03^{\mathrm{c}}$ & $1.62 \pm 0.05^{\mathrm{d}}$ \\
\hline (G9) $F^{*} L 3$ & $2.03 \pm 0.12$ & $1.21 \pm 0.04$ & $1.11 \pm 0.04^{\mathrm{bc}}$ & $1.49 \pm 0.13^{b c}$ & $1.80 \pm 0.07^{\mathrm{b}}$ & $2.63 \pm 0.13$ & $1.58 \pm 0.01^{\mathrm{c}}$ & $1.59 \pm 0.01^{\mathrm{d}}$ \\
\hline$P$-value & 0.5973 & 0.9762 & 0.0013 & 0.0091 & 0.0521 & 0.1721 & 0.0003 & $<.0001$ \\
\hline
\end{tabular}




\section{Metwally et al.}

exposed to flashing light regime had the lowest FCR. And, Farghly et al., (2019b) reported that hens exposed to intermittent lights for $20 \mathrm{~min} / \mathrm{h}+40 \mathrm{~min}$ of constant light had the lowest FCR when compared with the other groups .

On the other hand, Bayram and Özkan (2010) who reported that FCR were not affected by lighting treatment under the experimental conditions. Amakiri et al., (2011) reported insignificant differences in the FCR of broilers subjected to varying nocturnal lighting programs. Sun et al., (2017) reported that the FCR of broilers under the 3L:1D regimen was high.

We in an agreement with, Kheiri and Landy (2019) who reported that FCR it tended to improve in broiler chickens supplemented with 1- $\alpha(\mathrm{OH})$ D3 in combination with different concentrations of cholecalciferol in compare with broiler chickens fed basal diet or basal diet supplemented with $1-\alpha(\mathrm{OH})$ D3 alone.

Conversely, Landy et al., (2015) who reported that the supplementation of $5000 \mathrm{IU}$ cholecalciferol $/ \mathrm{kg}$ of diet contained $5 \mu \mathrm{g}$ of 1- $\alpha(\mathrm{OH}) \mathrm{D} 3 / \mathrm{kg}$ of diet significantly decreased feed efficiency of broiler chickens during starter period although it had not any significant effect on growth performance of broiler chickens during grower and finisher phases.

\section{Carcass traits}

The results of carcass traits as affected by light regimens and vitamin D3 levels and their interactions presented in (Table 5). There were insignificant effects due to the lighting programs on carcass traits of Sasso chicks except, the effect on abdominal fat it was significant at $(\mathrm{P} \leq 0.05)$. The chicks which raised under flash lighting program were the lowest than other lighting groups. Chicks which fed on diet with level 2 and 3 of vitamin D3 were the same significantly effect on thigh percentage they were higher than chicks which fed on diet with level 1 of vit. D3. While, chicks which fed on diet with level 2 and 3 of vitamin D3 were the same significantly effect on giblets percentage they were lower than chicks which fed on diet with level 1 of vit. D3. the rest of carcass traits had insignificant effects. There was insignificant effect due to the interaction between lighting programs and vitamin D3 levels on carcass traits except, the effect on abdominal fat it was significant at $(\mathrm{P} \leq 0.05)$ the chicks in groups 7,8 , and 9 which raised under flash lighting program were lowest than other groups.

Our study in same line with Farghly et al., (2019a) who reported that lighting programs did not significantly change the carcass traits. Also, Farghly and Makled (2015) they found non-significant differences in the percentages of the dressed carcass, drumstick, femur, breast, heart, and gizzard among all groups under light flashes, although the differences were significant $(\mathrm{P}<0.05)$ in the drumstick, liver and abdominal fat percentages. And, this result was consistent with the findings of Downs et al., (2006), who reported no significant effect in the cold carcass yield of birds exposed to different lighting program .

Reversely Olanrewaju et al., (2019) who showed that regular/intermittent photoperiod had higher live weight $(\mathrm{P}=0.043)$, carcass weight $(\mathrm{P}=0.037)$, carcass yield $(\mathrm{P}=0.034)$, and breast weight $(\mathrm{P}=0.035)$ in comparison with short/non-intermittent photoperiod. Lien et al., (2007) reported that an interaction effect on chilled carcass weight resulted in the $0.1 \mathrm{FC}-23 \mathrm{~L}$ treatment carcass weight being reduced an average of $78 \mathrm{~g}$ relative to the other 3 treatments. Intermittent lighting treatment effects reported by Das and Lacin (2014) caused lower breast yield in broilers when compared to CL (42.62\% vs. 44.76\%). However, Schwean-Lardner and Classen (2010) reported increased carcass yield with increasing length of photoperiod. Furthermore, these researchers observed an increase in breast meat yield and decreased whole leg percentage with increasing photoperiod length, in parallel to what was obtained from the studies of Downs et al., (2006) and Fidan et al.( $(\cdot+\mid \mathrm{V})$ ‘.

This result was consistent with the findings of Khan et al., (2009) showed that values of dressing percentage and breast meat yield in different groups indicated that there was no marked variation up to $1500 \mathrm{IU} / \mathrm{kg}$ VIT-D3 supplementation. Statistical analysis showed insignificant ( $p>0.05$ ) results in above parameters of broiler between levels of VIT-D3 200 and 1500 IU/kg However, birds fed diet with higher levels of VIT-D3 had significantly $(\mathrm{p}<0.05)$ the highest dressing percentage and breast meat yield.Our study in same line with Farghly et al., (2019a) who reported that lighting programs didn't significantly change the carcass traits. This result was consistent with the findings of Khan et al., (2009) who showed that values of dressing percentage and breast meat yield in different groups indicated that there was no marked variation up to $1500 \mathrm{IU} / \mathrm{kg}$ VIT-D3 supplementation.

\section{Some body organs}

The effects of lighting programs, vitamin D3 levels and their interactions on some body organs of Sasso broiler chicks are presented in (Table 6).

There was significant difference due to lighting programs on gall bladder at $(\mathrm{P} \leq 0.05)$. There were insignificant effects due to the lighting programs on the rest of a body organs of Sasso chicks. 
Egyptian J. Nutrition and Feeds (2021)

There was a significant effect due to vitamin D3 levels on heart and pancreas percentage at $(\mathrm{P} \leq 0.05)$. However, Chicks which fed on diet with level 2 and 3 of vitamin D3 were the same significantly effect on heart and pancreas percentages they were higher than chicks which fed on diet with level 1 of vit. D3. There was an interactions effect between lighting programs and vitamin D3 levels on liver, gizzard, pancreas and gall bladder percentages significantly at $(\mathrm{P} \leq 0.05)$.

These findings partially agree with those reported by Farghly and Makled (2015) who they found that flash lighting significantly affected on liver percentages. And, Abreu et al., (2011) who showed that lighting programs did not affect the heart, liver, gizzard, and abdominal fat percentages.

\section{CONCLUSION}

The results of this study indicated that supplement of vitamin D3 and continuous plus flash lighting program improved growth performance until marketing age.

Table (5): Effects of lighting programs, vitamin D3 levels and their interactions on carcass traits of broiler chicks.

\begin{tabular}{|c|c|c|c|c|c|c|c|}
\hline \multirow[b]{2}{*}{ Treatment } & \multicolumn{7}{|c|}{ Carcass trait } \\
\hline & $\begin{array}{l}\text { Live BW } \\
(\mathrm{g})\end{array}$ & Carcass $\%$ & $\begin{array}{c}\text { Breast } \\
\%\end{array}$ & $\begin{array}{c}\text { Thigh } \\
\%\end{array}$ & $\begin{array}{c}\text { D. carcass } \\
\%\end{array}$ & $\begin{array}{c}\text { Giblets } \\
\%\end{array}$ & $\begin{array}{c}\text { Abdominal } \\
\text { fat } \%\end{array}$ \\
\hline \multicolumn{8}{|l|}{ Lighting programs: } \\
\hline Continues (C) & $1219.44 \pm 15.58$ & $66.23 \pm 0.62$ & $21.95 \pm 0.59$ & $13.54 \pm 0.61$ & $71.10 \pm 0.74$ & $4.87 \pm 0.22$ & $2.19 \pm 0.03^{\mathrm{a}}$ \\
\hline $\begin{array}{l}\text { Continues+Flash } \\
\text { (CF) }\end{array}$ & $1251.67 \pm 35.18$ & $68.18 \pm 0.66$ & $22.05 \pm 0.56$ & $12.41 \pm 0.56$ & $73.02 \pm 0.66$ & $4.84 \pm 0.12$ & $2.15 \pm 0.06^{\mathrm{a}}$ \\
\hline Flash $(\mathrm{F})$ & $1222.78 \pm 23.19$ & $66.94 \pm 0.79$ & $22.49 \pm 0.57$ & $13.00 \pm 0.68$ & $71.77 \pm 0.90$ & $4.83 \pm 0.23$ & $1.71 \pm 0.03^{b}$ \\
\hline$P$-value & 0.6326 & 0.1535 & 0.7812 & 0.4463 & 0.2238 & 0.9915 & $<.0001$ \\
\hline \multicolumn{8}{|l|}{ Vit. D3 levels: } \\
\hline $\begin{array}{l}\text { Control level } 1 \\
\text { (L1) }\end{array}$ & $1255.56 \pm 29.14$ & $67.74 \pm 0.44$ & $21.52 \pm 0.60$ & $11.67 \pm 0.35^{\mathrm{b}}$ & $73.06 \pm 0.43$ & $5.32 \pm 0.17^{\mathrm{a}}$ & $1.96 \pm 0.09$ \\
\hline $\begin{array}{l}200 \text { IU level } 2 \\
\text { (L2) }\end{array}$ & $1211.67 \pm 27.35$ & $67.58 \pm 0.60$ & $22.64 \pm 0.62$ & $13.68 \pm 0.61^{\mathrm{a}}$ & $72.08 \pm 0.64$ & $4.50 \pm 0.06^{\mathrm{b}}$ & $2.05 \pm 0.09$ \\
\hline $\begin{array}{lll}400 & \text { IU level } 3 \\
\text { (L3) } & & \end{array}$ & $1226.67 \pm 19.36$ & $66.04 \pm 0.95$ & $22.34 \pm 0.43$ & $13.60 \pm 0.64^{\mathrm{a}}$ & $70.76 \pm 1.05$ & $4.72 \pm 0.20^{\mathrm{b}}$ & $2.03 \pm 0.08$ \\
\hline$P$-value & 0.4799 & 0.1869 & 0.3502 & 0.0251 & 0.1171 & 0.0028 & 0.7662 \\
\hline \multicolumn{8}{|l|}{ Interactions: } \\
\hline$(\mathrm{G} 1) \mathrm{C}^{*} \mathrm{~L} 1$ & $1218.33 \pm 31.80$ & $67.88 \pm 0.73$ & $20.91 \pm 1.25$ & $12.03 \pm 0.41^{\mathrm{abc}}$ & $73.20 \pm 1.03$ & $5.32 \pm 0.31$ & $2.18 \pm 0.06^{\mathrm{a}}$ \\
\hline$(\mathrm{G} 2) \mathrm{C}^{*} \mathrm{~L} 2$ & $1201.67 \pm 29.06$ & $65.92 \pm 0.74$ & $22.82 \pm 1.02$ & $14.58 \pm 1.51^{\mathrm{ab}}$ & $70.19 \pm 0.66$ & $4.28 \pm 0.09$ & $2.23 \pm 0.07^{\mathrm{a}}$ \\
\hline$(\mathrm{G} 3) \mathrm{C} * \mathrm{~L} 3$ & $1238.33 \pm 26.82$ & $64.90 \pm 1.11$ & $22.13 \pm 0.80$ & $14.01 \pm 0.49^{\mathrm{abc}}$ & $69.90 \pm 1.33$ & $5.01 \pm 0.42$ & $2.14 \pm 0.06^{\mathrm{a}}$ \\
\hline (G4) $\mathrm{CF}^{*} \mathrm{~L} 1$ & $1295.00 \pm 70.00$ & $67.65 \pm 0.85$ & $21.76 \pm 1.06$ & $11.45 \pm 0.99^{c}$ & $72.83 \pm 0.69$ & $5.18 \pm 0.23$ & $2.07 \pm 0.10^{\mathrm{a}}$ \\
\hline (G5) $\mathrm{CF}^{*} \mathrm{~L} 2$ & $1233.33 \pm 83.33$ & $69.54 \pm 0.48$ & $21.98 \pm 1.46$ & $13.93 \pm 0.92^{\mathrm{abc}}$ & $74.19 \pm 0.46$ & $4.65 \pm 0.03$ & $2.17 \pm 0.14^{\mathrm{a}}$ \\
\hline (G6) $\mathrm{CF}^{*} \mathrm{~L} 3$ & $1226.67 \pm 39.83$ & $67.36 \pm 1.69$ & $22.42 \pm 0.63$ & $11.84 \pm 0.37^{\mathrm{bc}}$ & $72.04 \pm 1.84$ & $4.68 \pm 0.16$ & $2.21 \pm 0.06^{\mathrm{a}}$ \\
\hline (G7) $\mathrm{F}^{*} \mathrm{~L} 1$ & $1253.33 \pm 52.94$ & $67.69 \pm 1.05$ & $21.88 \pm 1.15$ & $11.52 \pm 0.46^{\mathrm{c}}$ & $73.14 \pm 0.82$ & $5.45 \pm 0.41$ & $1.63 \pm 0.07^{b}$ \\
\hline (G8) $F^{*} \mathrm{~L} 2$ & $1200.00 \pm 28.87$ & $67.27 \pm 0.43$ & $23.13 \pm 1.04$ & $12.53 \pm 0.54^{\mathrm{abc}}$ & $71.85 \pm 0.42$ & $4.58 \pm 0.00$ & $1.74 \pm 0.04^{\mathrm{b}}$ \\
\hline (G9) $F^{*} \mathrm{~L} 3$ & $1215.00 \pm 45.37$ & $65.86 \pm 2.30$ & $22.47 \pm 1.08$ & $14.95 \pm 1.39^{\mathrm{a}}$ & $70.33 \pm 2.61$ & $4.47 \pm 0.42$ & $1.75 \pm 0.06^{\mathrm{b}}$ \\
\hline$P$-value & 0.9293 & 0.2872 & 0.9277 & 0.0569 & 0.2621 & 0.0927 & $<.0001$ \\
\hline
\end{tabular}

${ }^{a-c}$ Means in the same columns in each classification with different superscript are significantly different $P \leq 0.05$ 
Egyptian J. Nutrition and Feeds (2021), 24(1): 171-185

Table (6): Effects of lighting programs, vitamin D3 levels and their interactions on some body organs of broiler chicks.

\begin{tabular}{|c|c|c|c|c|c|}
\hline \multirow[t]{2}{*}{ Treatment } & \multicolumn{5}{|c|}{ Some body organs } \\
\hline & Liver\% & Gizzard\% & Heart\% & Pancreas\% & Gall bladder $\%$ \\
\hline \multicolumn{6}{|l|}{ Lighting programs: } \\
\hline Continues $(\mathrm{C})$ & $2.56 \pm 0.12$ & $1.93 \pm 0.18$ & $0.37 \pm 0.02$ & $0.18 \pm 0.02$ & $0.10 \pm 0.01^{\mathrm{a}}$ \\
\hline Continues+Flash & $2.37 \pm 0.15$ & $2.11 \pm 0.07$ & $0.36 \pm 0.02$ & $0.16 \pm 0.02$ & $0.08 \pm 0.01^{\mathrm{b}}$ \\
\hline Flash (F) & $2.53 \pm 0.16$ & $1.90 \pm 0.11$ & $0.40 \pm 0.02$ & $0.20 \pm 0.02$ & $0.08 \pm 0.00^{\mathrm{b}}$ \\
\hline$P$-value & 0.6115 & 0.4791 & 0.4352 & 0.2376 & 0.0077 \\
\hline \multicolumn{6}{|l|}{ Vit. D3 levels: } \\
\hline Control level 1 & $2.94 \pm 0.10^{\mathrm{a}}$ & $2.05 \pm 0.08$ & $0.33 \pm 0.02^{\mathrm{b}}$ & $0.13 \pm 0.01^{\mathrm{b}}$ & $0.08 \pm 0.00$ \\
\hline 200 IU level 2 & $2.16 \pm 0.08^{\mathrm{b}}$ & $1.95 \pm 0.13$ & $0.39 \pm 0.02^{\mathrm{a}}$ & $0.19 \pm 0.01^{\mathrm{a}}$ & $0.09 \pm 0.00$ \\
\hline 400 IU level 3 & $2.35 \pm 0.10^{\mathrm{b}}$ & $1.95 \pm 0.17$ & $0.42 \pm 0.02^{\mathrm{a}}$ & $0.21 \pm 0.01^{\mathrm{a}}$ & $0.08 \pm 0.01$ \\
\hline$P$-value & 0.0001 & 0.8377 & 0.0068 & 0.0004 & 0.1837 \\
\hline \multicolumn{6}{|l|}{ Interactions: } \\
\hline$(\mathrm{G} 1) \mathrm{C}^{*} \mathrm{~L} 1$ & $3.00 \pm 0.15^{\mathrm{a}}$ & $2.00 \pm 0.17^{\mathrm{abc}}$ & $0.31 \pm 0.02$ & $0.12 \pm 0.02^{\mathrm{c}}$ & $0.10 \pm 0.01^{\mathrm{a}}$ \\
\hline$(\mathrm{G} 2) \mathrm{C}^{*} \mathrm{~L} 2$ & $2.40 \pm 0.10^{\mathrm{bc}}$ & $1.46 \pm 0.04^{\mathrm{c}}$ & $0.42 \pm 0.05$ & $0.19 \pm 0.01^{\mathrm{ab}}$ & $0.10 \pm 0.01^{\mathrm{a}}$ \\
\hline$(\mathrm{G} 3) \mathrm{C}^{*} \mathrm{~L} 3$ & $2.29 \pm 0.05^{\mathrm{c}}$ & $2.33 \pm 0.40^{\mathrm{a}}$ & $0.39 \pm 0.02$ & $0.23 \pm 0.01^{\mathrm{a}}$ & $0.10 \pm 0.01^{\mathrm{a}}$ \\
\hline (G4) $\mathrm{CF} * \mathrm{~L} 1$ & $2.87 \pm 0.21^{\mathrm{ab}}$ & $2.00 \pm 0.09^{\mathrm{abc}}$ & $0.31 \pm 0.06$ & $0.14 \pm 0.01^{\mathrm{bc}}$ & $0.08 \pm 0.01^{\mathrm{ab}}$ \\
\hline (G5) CF*L2 & $1.94 \pm 0.10^{\mathrm{c}}$ & $2.34 \pm 0.10^{\mathrm{a}}$ & $0.37 \pm 0.03$ & $0.14 \pm 0.01^{\text {bc }}$ & $0.10 \pm 0.00^{\mathrm{a}}$ \\
\hline (G6) $\mathrm{CF} * \mathrm{~L} 3$ & $2.29 \pm 0.09^{c}$ & $2.00 \pm 0.07^{\mathrm{abc}}$ & $0.40 \pm 0.01$ & $0.19 \pm 0.04^{\mathrm{ab}}$ & $0.06 \pm 0.01^{\mathrm{b}}$ \\
\hline$(\mathrm{G} 7) \mathrm{F}^{*} \mathrm{~L} 1$ & $2.95 \pm 0.24^{\mathrm{a}}$ & $2.14 \pm 0.20^{\mathrm{a}}$ & $0.36 \pm 0.04$ & $0.14 \pm 0.02^{\mathrm{bc}}$ & $0.08 \pm 0.01^{\mathrm{ab}}$ \\
\hline (G8) $F^{*} \mathrm{~L} 2$ & $2.16 \pm 0.02^{\mathrm{c}}$ & $2.04 \pm 0.04^{\mathrm{ab}}$ & $0.38 \pm 0.02$ & $0.24 \pm 0.01^{\mathrm{a}}$ & $0.09 \pm 0.01^{\mathrm{ab}}$ \\
\hline (G9) $\mathrm{F}^{*} \mathrm{~L} 3$ & $2.47 \pm 0.32^{\mathrm{abc}}$ & $1.53 \pm 0.09^{\mathrm{bc}}$ & $0.47 \pm 0.01$ & $0.22 \pm 0.01^{\mathrm{a}}$ & $0.07 \pm 0.00^{\mathrm{b}}$ \\
\hline$P$-value & 0.0023 & 0.0218 & 0.0704 & 0.0013 & 0.0158 \\
\hline
\end{tabular}

\section{ACKNOWLEDGMENTS}

The author express appreciation for the support from the supervision committee (Prof. Dr. Mohamed Metwally and Prof. Dr. Mohamed Farghly Alm El-Deen) and all staff member of Poultry Production Department, Faculty of Agriculture, Assiut University.

\section{REFERENCES}

Abbas, A.O., Alm Ei-Dein, A.K., Desoky, A.A. And Galal, M.A.A. (2008). The effects of photoperiod programmes on broiler chicken performance and immune response. Inter. J. of Poult. Sci. 7: 665-671.

Abbasi, T., M. Shakeri, M. Zaghari and H. Kohram. (2017). Growth performance parameters, bone calcification and immune response of in ovo injection of 25-hydroxycholecalciferol and vitamin K3 in male ross 308 broilers. Theriogenology 90: 260-265.

Abreu, V. M. N., P. G. de Abreu, A. Coldebella, F. R. F. Jaenisch, and D. P. de Paiva. (2011). Curtain color and lighting program in broiler production: II. Carcass and parts yield and abdominal fat deposition. R. Bras. Zootec. 40:2035-2038.

Adhikari, R., D. White, J. D. House, and W. K. Kim. (2020). Effects of additional dosage of vitamin D3, vitamin D2, and 25-hydroxyvitamin D3 on calcium and phosphorus utilization, egg quality and bone mineralization in laying hens. Poult. Sci. 99: 364-373.

Amakiri, A. O., O. J. Owen, and E. S. Etokeren. (2011). Broiler chicken's growth rate in three different nocturnal lightingregimes. Afr. J. Food Agric. Nutr. Dev. 11: https://www.ajfand.net/Volume11/No5/Amakiri9610.pdf

Arowolo, M. A., J.H. He, S.P. He and T.O. Adebowale. (2019). The implication of lighting programmes in intensive broiler production system. W. Poult. Sci. A. 75: 17-28.

Aviagen (2014). Lighting for broiler, housing, and environment. Arbor Acre broiler management: handbook, No. 100. 
Bayram, A. and S. Özkan (2010). Effects of a 16-hour light, 8-hour dark lighting schedule on behavioral traits and performance in male broiler chickens. J. Appl. Poult. Res. $19: 263-273$.

Berri, C., C. Praud, E. Godet, And M. J. Duclos. (2013). 'Effect of Dietary 25-Hydroxycholecalciferol on Muscle Tissue and Primary Cell Culture Properties in Broiler Chicken. In: Bookof Abstracts (P. 6 P.).' 21th European Symposium on the Quality of Poultry Meat, Bergamo, Italy, September 15-19. World's Poultry Science Journal 69 supplement.

Bozkurt, M., S. Yalçin, B. Koçer, A. E. Tüzün, H. Akşit, S. Özkan, M. Uygun, G. Ege, G. Güven and O. Yildiz. (2017). Effects of enhancing vitamin D status by 25-hydroxycholecalciferol supplementation, alone or in combination with calcium and phosphorus, on sternum mineralisation and breast meat quality in broilers. Br. POULT. SCI., 58, 4, 452-461.

Cho T. Z. A., Muhammad Bilal Sadiq, Pairat Srichana, and Anil Kumar Anal. (2019). Vitamin D3 enhanced intestinal phosphate cotransporter genes in young and growing broilers. Poult. Sci. 99:20412047.

DAS, H. and LACIN, E. (2014). The effect of different photoperiods and stocking densities on fattening performance, carcass and some stress parameters in broilers. Israel J. of Vet. Med. 69: 211- 220.

Downs, K.M., Lien, R.J., Hess, J.B., Bilgili, S.F. And Dozier, W.A. (2006). The effects of photoperiod length, light intensity, and feed energy on growth responses and meat yield of broilers. J. App. Poult. Res. 15: 406-416.

Duncan, D.B. (1955). The multiple range and multiple F.test. Biometric.11: 1-42.

Farghly, M. F. A., and H. H. M. Hassanien. (2012). Effect of feed frequencies and durations on performance of broiler chicks. Egypt. Poult. Sci. J. 32:273-288.

Farghly, M. F. A., and M. N. Makled. (2015). Application of intermittent feeding and flash lighting regimens in broiler chickens management. Egypt. J. Nutr. Feeds 18:261-276.

Farghly, M.F.A., O. H. El-Garhy and Reham M. Ali (2017). Application of flashed lighting program in naked neck chickens (Sharkasi) management. Egypt. Poult. Sci., 37: 1041-1067.

Farghly, Mohamed F., Khalid M. Mahrose, Enas, A. M. Ahmad, Zaib Ur Rehman and Shengqing Yu. (2019a). Implementation of different feeding regimes and flashing light in broiler chicks. Poult. Sci. $0: 1-9$.

Farghly, Mohammed F. A., Khalid M. Mahrose, Zaib Ur Rehman, Shengqing Yu, Mostafa G. Abdelfattah, and Osama H. El-Garhy. (2019b). Intermittent lighting regime as a tool to enhance egg production and eggshell thickness in Rhode Island Red laying hens. Poult. Sci. 0:1-7.

Fidan, D.E., Nazligül, A., Türkyilmaz, M.K., Karaarslan, S. And Kaya, M. (2017) Effects of photoperiod length and light intensity on performance, carcass characteristics and heterophil to lymphocyte ratio in broilers. Kafkas Universitesi Veteriner Fakultesi Dergisi 23: 39-45.

Garcia, A. F. Q. M., A. E. Murakami, C. R. D. A. Duarte, I. C. O. Rojas, K. P. Picoli, and M. M. Puzotti. (2013). Use of vitamin $\mathrm{d} 3$ and its metabolites in broiler chicken feed on performance, bone parameters and meat quality. Asian-Australas. J. Anim. Sci. 263:408-415.

Han, J.C., Yang, X.D., Zhang, L.M., Li, W.L., Zhang, T., Zhang, Z.Y., Ya, J.H., (2009). Effects of $1 \alpha-$ Hydroxycholecalciferol and phytase on growth performance, tibia parameter and meat quality of 1 - to 21-d-old broilers. Asian Aust. J. Anim. Sci. 22: 857-864.

Hutton, K. C., M. A. Vaughn, G. Litta, B. J. Turner, And J. D. Starkey. (2014). 'Effect of Vitamin D Status Improvement with 25- Hydroxycholecalciferol on Skeletal Muscle Growth Characteristics and Satellite Cell Activity in Broiler Chickens.' J. of Anim. Sci. 92: 3291-3299.

Kahn, S.H., R. Shahid, A. A. Mian, R. Sardar and M. A. Anjum. (2010). Effect of the level of cholecalciferol supplementation of broiler diets on the performance and tibial dyschondroplasia. Journal of Animal Physiology and Animal Nutrition. 94:584-593.

Khan, S. H., R. Shahid, A. A. Mian, R. Sardar and M. A. Anjum. (2009). Effect of the level of cholecalciferol supplementation of broiler diets on the performance and tibial dyschondroplasia. J. Anim. Physiology and Anim. Nutri., 94:584-593.

Kheiri, F. and N. Landy (2019). The effects of dietary 1-alpha-hydroxycholecalciferol individually or in combination with different levels of cholecalciferol on growth performance and tibia criteria in broiler chickens. Liv. Sci. 221: 172-176.

Landy, N., Toghyani, M., Bahadoran, M., Eghbalsaied, S., (2015). The effects of 1alpha-hydroxycholecalciferol supplementation on performance and tibia parameter of broiler chickens. Res. Opin. Anim. Vet. Sci. 5: 342-347.

Liboni, B.S., Yoshida, S.H., Pacheco, A., Montanha, F.P., Souza, L.F.A., Astolphi, J.L. And Astolphi, M.Z. (2013). Diferentes programas de luz na criação de frangos de corte. Revista Científica Eletrônica de Medicina Veterinária, nr. 20. 


\section{Metwally et al.}

Lien, R. J., J. B. Hess, S. R. Mc Kee, S. F. Bilgili, and J. C. Towsend. (2007). Effect of light intensity and photoperiod on live performance, heterophil-to-lymphocyte ratio, and processing yields of broilers. Poult. Sci. 86:1287-1293.

Metwally, M. A., M. F. A. Farghly, R. M. Ali and M.E. Ghonime (2015). Effect of interrelationships between light type and vitamin D3 levels on growing Dandrawi chickens performance. Egyptian J. Nutrition and Feeds, 18(2) Special Issue (Abstract).

NRC (1994). Nutrients Requirements of Poultry. 9th ed. National Research Council, National Academy Press, Washington D.C., USA .

Nelson, Jill R., Joey L. Bray, Juliette Delabbio, and Gregory S. Archer. (2020). Comparison of an intermittent, short-dawn/dusk photoperiod with an increasing, long-dawn/dusk photoperiod on broiler growth, stress, and welfare. Poult. Sci. 99:3519-3524.

Okafor, B. B. and G. A. Kalio. (2017). Effect of Graded Levels of Vitamin D3 (Cholecalciferol) on the Performance, Carcass and Organ Weights of Broilers Chickens. J. Agri. Eco. Res. Inter. 12: 1-7.

Olanrewaju, H. A., J. L. Purswell, S. D. Collier, and S. L. Branton. (2012). Influence of photoperiod, light intensity, and their interaction on growth performance and carcass characteristics of broilers grown to heavy weights. Int. J. Poult. Sci. 11:739- 746.

Olanrewaju, H. A., W. W. Miller, W. R. Maslin, S. D. Collier, J. L. Purswell, and S. L. Branton. (2019). Interactive effects of light-sources, photoperiod, and strains on growth performance, carcass characteristics, and health indices of broilers grown to heavy weights. Poult. Sci. 98:6232-6240.

Olanrewaju, H. A., W. W. Miller, W. R. Maslin, S. D. Collier, J. L. Purswell, and S. L. Branton (2018). Influence of light sources and photoperiod on growth performance, carcass characteristics, and health indices of broilers grown to heavy weights. Poult. Sci. 97:1109-1116.

Onbasılar, E. E., H. Erol1, Z. Cantekin, and U. Kaya. (2007). Influence of intermittent lighting on broiler performance, incidence of tibial dyschondroplasia, tonic immobility, some blood parameters and antibody production. Asian-Australas. J. Anim. Sci. 20:550-555.

Paul RC, Ahmad N, Moinuddin MA, Hasan N. (2010). Effects of administration of multivitamins and enzymes for broilers either singly or in combination on body weight and haematobiochemical parameters. J. Bangladesh Agri. Uni. 8:39-44.

Pesti, G. M., and H. L. Shivaprasad. (2010). The influence of excessive levels of $1 \alpha$ hydroxycholecalciferol on the growth and tissue appearance of market weight chickens. J. Appl. Poult. Res. $19: 349-353$.

Ramo Rao, S. V., M. V. L. N. Raju, A. K. Panda, G. Shyam Sunder, and R. P. Sharma. (2009). Performance and bone mineralisation in broiler chicks fed on diets with different concentrations of cholecalciferol at a constant ratio of calcium to non-phytate phosphorus. Br. Poult. Sci. 504:528-535.

SAS. (2009). User's Guide. Version, 9.2, 2002-2009, SAS institute Inc., Cary, NC, USA.

Schwean-Lardner, K. And Classen, H. (2010). Lighting for broilers. Aviagen Arbor Acre broiler management: handbook, No. 8.

Schwean-Lardner, K., Vermette, C., Leis, M. And Classen, H.L. (2016). Basing Turkey Lighting Programmes on Broiler Research: A Good Idea? A Comparison of 18 Day-length effects on broiler and turkey welfare. Animals (Basel) 6: 27.

Sun, Y.Y., S. Tanga, Y. Chenb, D.L. Lia, Y.L. Bic, D.K. Huaa, C. Chena, Q.Y. Luoa, L. Yanga, J.L. Chen. (2017). Effects of light regimen and nutrient density on growth performance, carcass traits, meat quality, and health of slow-growing broiler chickens. Livestock Sci. 198: 201-208.

Vignale, K., E. S. Greene, J. V. Caldas, J. A. England, N. Boonsinchai,P. Sodsee, E. D. Pollock, S. Dridi, And C. N. Coon. (2015). '25- Hydroxycholecalciferol Enhances Male Broiler Breast Meat Yield through the mTOR Pathway.' J. of Nutri. 145: 855-863.

Yang, H., H. Xing, Z. Wang, J. Xia, Y. Wan, B. Hou, and J. Zhang. (2015). Effects of intermittent lighting on broiler growth performance, slaughter performance, serum biochemical parameters and tibia parameters. Ital. J. Anim. Sci. 14(4):41-43.

Zeman, M., P. Pavlik, D. Lamosova, I. Herichova, and E. Gwinner. (2004). Entrainment of Rhythmic Melatonin Production by Light and Temperature in the Chick Embryo. Avian \& Poul. Biolog. Rev. 15:197-204. 


\author{
محمد متولى أحمد و محمد فرغلى علم الدين وطه شراقة

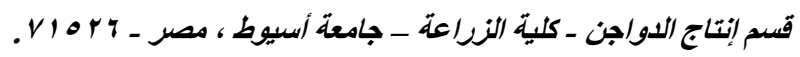

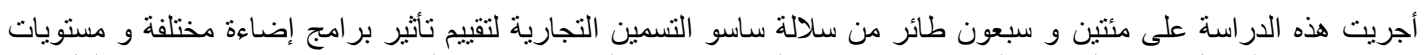

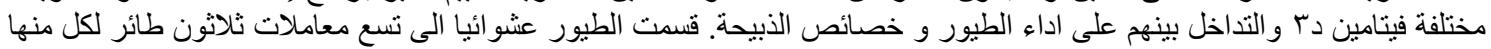

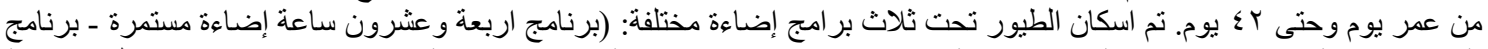

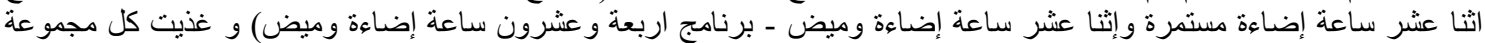

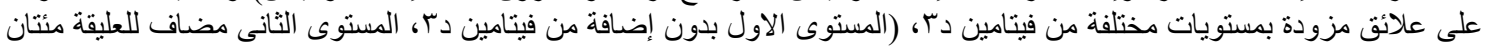

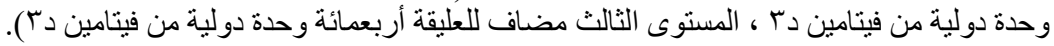

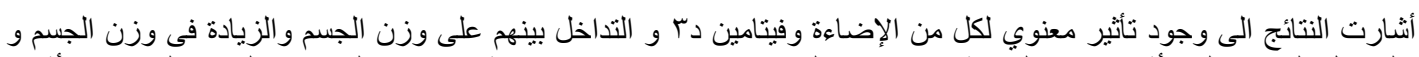

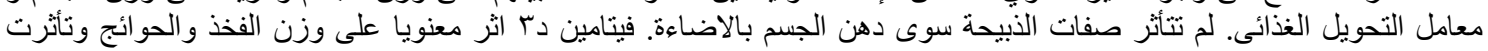

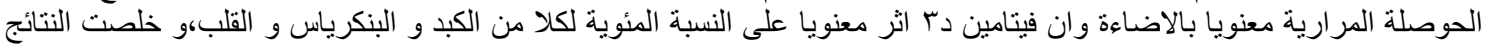

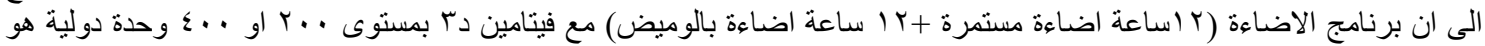
الذى اعطى افضل النتائج بالنسبة للصفات المداء المدروسة. 